[Agr. Biol. Chem., Vol. 29, No. 12, p. 1069 1073, 1965]

\title{
Studies on Biochemistry of the Thiobacilli
}

\section{Part VII. Metabolism of Tetrathionate by $T$. thiooxidans}

\author{
By Masayo Okuzum \\ Tokyo University of Fisheries \\ Received October 20, 1964
}

\begin{abstract}
Quantitative oxidation of tetrathionate to sulfate was achieved with freshly harvested cells of $T$. thiooxidans; $\mathrm{pH}$ optimum for the oxidation of tetrathionate by the washed cells was $2 \sim 3$, and the activity fell markedly at $\mathrm{pH}$ above 3.5 .

Tetrathionate might be enzymatically dismuted to pentathionate and trithionate under anaerobic conditions with crude extracts of $T$. thiooxidans; $\mathrm{pH}$ optimum for the reaction was about 2.7 and the activity fell strikingly at $\mathrm{pH} 4.7$. The formed trithionate might be further hydrolyzed to thiosulfate and sulfate.
\end{abstract}

Gleen and Quastel ${ }^{6}{ }^{1}$ noted that soil enriched with sulfur-oxidizing bacteria by perfusion with thiosulfate will oxidize tetrathionate without a lag phase and at the same rate as thiosulfate.

Tetrathionate is oxidized rapidly by $T$. thioparus, ${ }^{1} T$. denitrificans, ${ }^{2}$ and by the green sulfur bacterium Chlorobium thiosulfatophilum. ${ }^{31}$ Parker and Prisk" reported that Thiobacillus $X$ (apparently identical with $T$. thioparus) oxidized tetrathionate, but failed to find tetrathionate oxidation with $T$ thioparus and $T$. thiooxidans. Vishniac et al.," however, believed that Parker et al. might have worked with virtually inactive suspensions, and reported that $T$. thioparus grown without $\mathrm{Fe}^{2+}$ and $\mathrm{Mn}^{2+}$, was unable to oxidize thiosulfate to completion.

The fate of tetrathionate is obscure, but there are some evidences that trithionate or

1) W. Vishniac, J. Bacteriol., 64, 363 (1952).

2) K. Baalsrud, and K.S. Baalsrud, Arch. Mikrobiol, 20, 34 (1954).

3) H. Larsen, J. Bacteriol., 64, 187 (1952)

4) C. D. Parker, and J. Prisk, J. Gen. Microbiol, 8, 344 (1953).

5) R. L. Starkey, J. Gen. Physiol., 18, 325 (1935).

6) H. Gleen and J. H. Quastel, Appl. Microbiol., 1, 70 (1953).

7) H. Tamiya, K. Haga, and H. Huzisige, Acta Phytochim. (Japan), 12, 173 (1941).

8) W. Vishniac and M. Santer, Bacteriol. Rev., 21, 195 (1957). a closely related compound is formed during tetrathionate oxidation. ${ }^{13.141}$

Tamiya et al. ${ }^{7.121}$ reported that tetrathionate was nonbiologically dismuted to trithionate and pentathionate (equation 1).

$$
2 \mathrm{~S}_{4} \mathrm{O}_{6}^{2-} \longrightarrow \mathrm{S}_{3} \mathrm{O}_{6}^{2-}+\mathrm{S}_{5} \mathrm{O}_{6}^{2-}
$$

On the other hand, according to Vishniac's investigations, ${ }^{1.81}$ tetrathionate seems to undergo a sort of oxidation which, at least in part, give rise to trithionate, and his manometric data were in agreement with a quantitative conversion of tetrathionate to trithionate (equation 2).

$$
3 \mathrm{~S}_{4} \mathrm{O}_{6}^{\prime \prime-}+2.5 \mathrm{O}_{2}+\mathrm{H}_{2} \mathrm{O} \longrightarrow 4 \mathrm{~S}_{3} \mathrm{O}_{6}^{2-}+2 \mathrm{H}^{+}
$$

The further innestigation on the biological conversion of tetrathionate are reported in this paper.

\section{MATERIALS AND METHODS}

\section{Organism and crude extracts}

The organism used throughout this studies was Thiobacillus thiooxidans which was isolated in our laboratory. Cells were cultured and harvested by the same procedures as described in the previous paper. ${ }^{10)}$

13) A.S. Saslawsky, Centr. Bakteriol. Parasitenk., Abt II, 72,236 (1927).

14) I. P. Lange-Posdeeva, Arch. Sci. Biol. (USR), 30, 189 (1930). 
The washed cells were suspended in $0.1 \mathrm{M}$ phosphate buffer $(\mathrm{pH} 7.0$ ) at a final concentration of $14 \sim 16 \mathrm{mg}$ dry weight per $\mathrm{ml}$. The suspension was exposed to a Raytheon sonic oscillator $(20 \mathrm{kc} / \mathrm{sec}$, $200 \mathrm{~W}$ ) for fifteen minutes and centrifuged in the cold for thirty minutes at 12,000 r.p.m. to remove intact cells and deblis. Solid ammonium sulfate was added to the supernatant with stirring up to $80 \%$ saturation. $\mathrm{pH}$ of the solution was kept at 7.0 with ammonium hydroxide during the ammonium sulfate fractionation. The precipitate was collected and dissolved in $0.1 \mathrm{M}$ phosphate buffer ( $\mathrm{pH} \mathrm{7.0)}$. The $\mathrm{pH}$ of the crude extracts obtained in this way was carefully adjusted to about $\mathrm{pH} 3.5$ with $1 \mathrm{~N}$ $\mathrm{H}_{2} \mathrm{SO}_{4}$.

Experiments were conducted with the crude extracts except the special cases, in which the conditions were particullary noted somewhere else.

\section{Substrates}

Sodium tetrathionate was synthesized according to Auerbach's method, 9) by the oxidation of sodium thiosulfate with iodine, and the product obtained was recrystallized three times from $50 \%$ ethanol.

\section{Measurement of Tetrathionate Oxidation}

The tetrathionate oxidation was followed by the oxygen uptake using Warburg manometers. After cessation of the reactions, the residual tetrathionate and formed other compounds were determined.

\section{General Procedure of the Experiments of Tetra- thionate Dismutation}

Tetrathionate dismutation was carried out under anaerobic conditions in usual Thunberg tubes $1.8 \mathrm{~cm}$ external diameter). The crude extracts and some other reagents were placed in the main compartment and tetrathionate was added from the side arm. The reactions were carried out at $29 \sim 30^{\circ} \mathrm{C}$, and after a certain period of incubation, the residual tetrathionate and formed trithionate, pentathionate and sulfate were immediately determined.

\section{Determinations and paperchromatographys}

Determinations and paperchromatographys of inorganic sulfur compounds were by the methods as described in the previous paper. ${ }^{\text {to }}$

\section{RESULTS AND DISCUSSION}

\section{Effect of pH on the Oxidation of Tetrathionate by Washed Cells}

9) F. Auerbach and I. Koppel. (editors) 1927. "Handbuck der anorganischen chemie," 4, pt. 1, Hirzel Leipzig.

10) M. Okuzumi and Y. Kita, This Journal 29, 1063 (1965).
Iwatsuka and Mori $^{111}$ described that a slight uptake of oxygen by washed cells of $T$ thiooxidans was observed at $\mathrm{pH} 3.0 \sim 5.0$ when sodium tetrathionate was used as the substrate.

The author also studied manometrically the effect of $\mathrm{pH}$ on the oxidation of tetrathionate by washed cells.

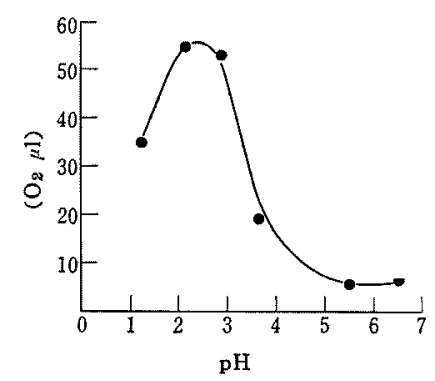

FIG. 1. Effect of $\mathrm{pH}$ on Oxidation of Tetrathionate by Washed Cells of $T$. thiooxidans.

Each reaction mixture contained $1.0 \mathrm{ml}$ of cell suspension (cells: $8 \mathrm{mg}$ dry weight), and $15 \mu$ moles of sodium tetrathionate to total volume of $2.3 \mathrm{ml}$. $\mathrm{pH}$ was adjusted to desired value by $1 \mathrm{~N} \mathrm{H}_{2} \mathrm{SO}_{4}$. Incubation was durated for 45 minutes at $30^{\circ} \mathrm{C}$.

As shown in Fig. 1, the $\mathrm{pH}$ optimum for the oxidation by the washed cells lay at about $2 \sim 3$ and the activity fell markedly at about 3.7. $\mathrm{HgNO}_{3}$ test and the paper-chromatography at the end of the experiments indicated that a most part of tetrathionate remained without being utilized in the reaction mixture of $\mathrm{pH} 3.7$ and a slight amount of both thiosulfate and trithionate was formed. Although Parker and Prisk ${ }^{4}$ failed to find tetrathionate oxidation with $T$. thiooxidans, this might be caused either by incubation at $\mathrm{pH}$ above 5 or by use of virtually inactive cells.

According to Vishniac's data, ${ }^{1 /}$ tetrathionate was remarkably utilized even at $\mathrm{pH} 7.0$ washed cells of $T$. thioparus, but in our experiments, the freshly harvested cells of $T$ thiooxidans were unable to utilize tetrathionate at $\mathrm{pH} 7.0$. It is interesting that the $\mathrm{pH}$ curve obtained with the washed cells for tetrathionate oxidation was nearly similar to that obtained from

11) H. Iwatsuka and T. Mori, Plant and Cell Physiol., (Tokyo) 1, 163 (1960). 


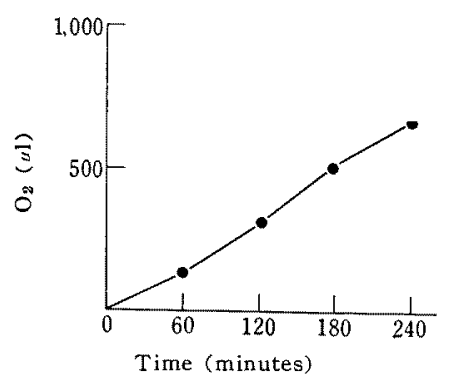

FIG. 2. Oxidation of Tetrathionate by Washed Cells of $T$. thiooxidans.

The reaction mixture $(\mathrm{pH} 3.0)$ contained $2.0 \mathrm{ml}$ of the same suspension as employed in the above experiment, and 10 $\mu$ moles of tetrathionate to total volume of $2.3 \mathrm{ml}$. The reaction was carried out at $30^{\circ} \mathrm{C}$ with Warburg manometer.

thiosulfate oxidation.

Since tetrathionate oxidation took place most readily at $\mathrm{pH} 3$ with the washed cells, manometric experiments of complete oxidation of tetrathionate to sulfate was, further, carried out at the $\mathrm{pH}$ value as mentioned above (Fig. 2).

As shown in Fig. 2, T. thiooxidans oxidized tetrathionate at a single linear rate until the oxidation was complete. When $10 \mu$ moles of tetrathionate was supplied, the oxygen uptake commenced after about 5 to 10 minutes of induction period, and it proceeded thereafter almost linearly with time for about 4 hours to attain finally (in almost six hours) a stationary level. About $780 \mu \mathrm{l}$ of oxygen uptake per $10 \mu$ moles of the substrate was observed, and the value was equivalent to about 35 $\mu$ moles. Further, the presence of thiosulfate, trithionate, tetrathionate, and sulfite in the reaction mixture after cessation of the reaction was not indicated by addition of $I_{2}$ and $\mathrm{HgNO}_{3}$ reagents. These substances were not identified by the paper chromatography. These results indicated that the quantitative oxidation of tetrathionate to sulfate was achieved with wased cells of $T$. thiooxidans (equation 3).

$$
\mathrm{S}_{4} \mathrm{O}_{6}^{2-}+3.5 \mathrm{O}_{2}+3 \mathrm{H}_{2} \mathrm{O} \longrightarrow 4 \mathrm{SO}_{4}^{2--}+6 \mathrm{H}^{+}
$$

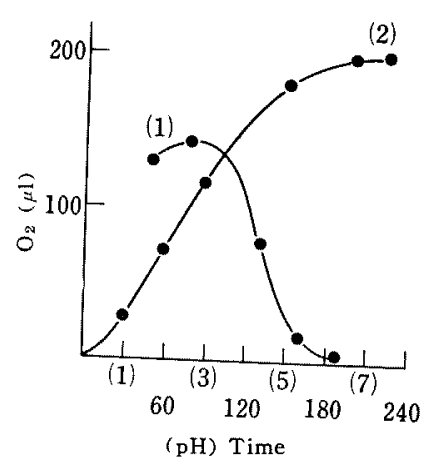

FIG. 3. Effect of $\mathrm{pH}$ on Oxidation of Tetrathionate by Crude Extracts of $T$. thiooxidans.

1) $\mathrm{pH}$ effect: Each reaction mixture contained $2.0 \mathrm{ml}$ of crude extracts, and $20 \%$ moles of tetrathionate to total volume of $2.3 \mathrm{ml}$.

2) Relationship between time course and oxidation of tetrathionate: The reaction mixture had the same composition as described above, except that the $\mathrm{pH}$ was 3.0 .

Both the reactions were carried out at $30^{\circ} \mathrm{C}$ with Warburg manometer: and incubation period in the case of (1) was 120 minutes,

\section{Effect of $\mathrm{pH}$ on the Oxidation of Tetrathionate by Crude Extracts}

As shown in Fig. 3, the $\mathrm{pH}$ optimum for the oxidation lay at about 3 , and the activity fell markedly at $\mathrm{pH}$ above 3.3 ; consequently, the result was similar to that obtained with the washed cells.

Further manometric experiment of the oxidation of tetrathionate was carried out at $\mathrm{pH}$ 3.0 with the same extract as employed in the above experiment.

The oxygen uptake commenced after about five minutes of induction period, thereafter proceeded almost linearly with time for about 210 minutes to attain finally a stationary level.

Oxygen consumption was about $200 \mu \mathrm{l}$ (equivalent to $8.9 \mu$ moles) after 4 hours, and no residue of tetrathionate in the reaction mixture at the end of the incubation was indicated by the addition of $\mathrm{HgNO}_{3}$ reagent. Therefore, $8.9 \mu$ moles of oxygen consumed are equivalent to about a half of $20 \mu$ moles of tetrathionate added initially, and this is in good agreement to the result of the previous paper. ${ }^{101}$ 
Decomposition of Tetrathionate under Anaerobic Condition

According to Tamiya's report, ${ }^{71}$ tetrathionate was nonenzymatically dismuted to trithionate and pentathionate (equation 1).

In our manometric experiments on the tetrathionate oxidation, the lag phase was observed for first ten minutes. Concerning the occurrence of lag phase, it is expected that tetrathionate may be dismuted to tri- and pentathionate, which may be further oxidized.

Thus, experiments on the dismutation of tetrathionate were conducted with the crude extracts under anaerobic condition. The result is shown in Table I.

TABLE I. ANAERoBic ReaCtion OF Tetrathionate BY CRUDE EXTRACTS OF $T$ thiooxidans

$\begin{array}{cccc}\mathrm{S}_{2} \mathrm{O}^{2-} & \mathrm{S}_{3} \mathrm{O}_{6}^{2-} & \mathrm{S}_{5} \mathrm{O}_{6}^{2-} & \mathrm{S}_{4} \mathrm{O}_{6}^{2-} \\ \text { formed } & \text { formed } & \text { formed } & \text { formed } \\ \text { ( } \mu \text { moles }) & \text { ( } \mu \text { moles }) & (\mu \text { moles }) & (\mu \text { moles) }\end{array}$

\begin{tabular}{|c|c|c|c|c|}
\hline $\begin{array}{l}\text { Crude } \\
\text { extracts }\end{array}$ & 4.4 & 7.2 & 6.3 & 81.9 \\
\hline Heated & 0.0 & 0.0 & 0.0 & 99.2 \\
\hline
\end{tabular}

Each $11.0 \mathrm{ml}$ of the reaction mixtures $(\mathrm{pH} \mathrm{3.0)}$ contained $5.0 \mathrm{ml}$ of crude extracts, $600 \mu$ moles of phosphate and 100 $\mu$ moles of tetrathionate. Incubation was continued for 60 minutes at $30^{\circ} \mathrm{C}$ under anaerobic condition.

Heated extract: The extract was boiled at $100^{\circ} \mathrm{C}$ for 5 minutes.

Firstly, since equimolar trithionate and pentathionate were formed, the dismutation of tetrathionate may take place, as indicated in equation 1. Secondly, it is considered that the heated crude extracts do not attack tetrathionate, since consumption of tetrathionate was little after one hour incubation. Therefore, the tetrathionate dismutation observed with the crude extracts must be an enzymatic reaction. Thirdly, the formation of thiosulfate was observed, and it is considered that the thiosulfate formation may be attributed to reduction of tetrathionate, or to decomposition or either the formed trithionate or pentationate. Consequently, the oxygen uptake observed in manometric experiments of the tetrathionate oxidation may not be attributed to the oxidation of tetrathionate itself. It is postulated that, under aerobic conditions tetra- thionate may be first dismuted enzymatically to yield trithionate and pentathionate, which may be further oxidized to consume oxygen secondarily.

\section{Effect of pH on the Decomposition of Tetra- thionate}

In order to determine optimal $\mathrm{pH}$ for the tetrathionate decomposition under anaerobic condition, the experiment was conducted with the crude extracts at such $\mathrm{pH}$ values as indicated in Table II.

TABLE II. EFFECT OF $\mathrm{pH}$ ON THE DECOMPOSITION OF TETRATHIONATE BY CRUDE ExTRACTS

$\begin{array}{cccc}\mathrm{pH} & \begin{array}{c}\mathrm{S}_{5} \mathrm{O}_{6}^{2-} \\ \text { formed } \\ (\mu \text { moles })\end{array} & \begin{array}{c}\mathrm{S}_{2} \mathrm{O}_{3}^{2-} \\ \text { formed } \\ (\mu \text { moles })\end{array} & \begin{array}{c}\mathrm{S}_{4} \mathrm{O}_{6}^{2-} \\ \text { residue } \\ (\mu \text { moles) }\end{array} \\ 1.7 & 32.4 & 38.1 & 11.6 \\ 2.8 & 36.8 & 43.2 & 2.9 \\ 4.7 & 0 & 0 & 94.8 \\ 6.4 & 0 & 0 & 95.3\end{array}$

Each reaction mixture contained $5.0 \mathrm{ml}$ of crude extracts, $500 \mu$ moles of phosphate and $100 \mu$ moles of tetrathionate to total volume of $6.5 \mathrm{ml}$. $\mathrm{pH}$ was adjusted to desired value by $1 \mathrm{~N} \mathrm{H}_{2} \mathrm{SO}_{4}$. All reaction mixtures were incubated at $30^{\circ} \mathrm{C}$ for 180 minutes under anaerobic condition.

The $\mathrm{pH}$ optimum for the decomposition lay at about 2.7 , and activity fell strikingly at $\mathrm{pH}$ 4.7. This result was similar to the result obtained from the manometric experiment on the effect of $\mathrm{pH}$ for the tetrathionate oxidation (Fig. 2). These results suggest that, tetrathionate itself is not oxidized, but is dismuted enzymatically to trithionate and pentathionate, which may be secondarily oxidized to somethings.

\section{Quantitative Analysis on Products Obtained in} Anaerobic Reaction of Tetrathionate

In above experiments, thiosulfate was formed in anaerobic reactions of tetrathionate, but whether the formation of thiosulfate was attributed to the reduction of tetrathionate itself or to secondary conversion of the products formed by dismutation of tetrathionate remained unknown. Thus, experiments were carried out in order to investigate relations between time course and thiosulfate formation under anaerobic conditions with crude ex- 


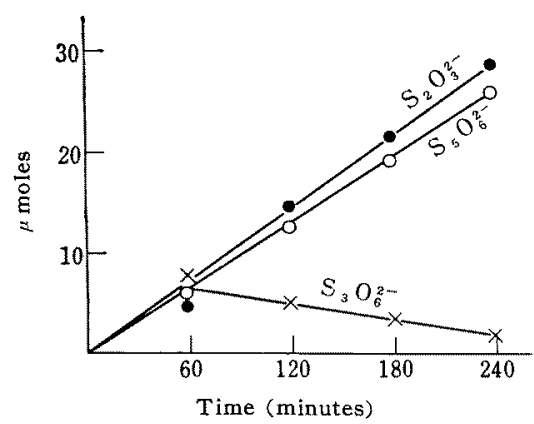

FIG. 4. Decomposition of Tetrathionate by Crude Extracts.

The reaction mixture contained $5 \mathrm{ml}$ of crude extracts, $500 \mu$ moles of phosphate and $100 \mu$ moles of tetrathionate to total volume of $7.0 \mathrm{ml}$. The reaction was carried out at $30^{\circ} \mathrm{C}$ under anaerobic condition.

tracts. The result is illustrated in Fig. 4.

As shown in the figure, the formation of pentathionate proceeded linearly from the beginning. The formation of thiosulfate commenced after a while, and it proceeded thereafter almost linearly with time. Equimolar formation of thiosulfate and pentathionate was observed during about three hours' incubation. In this connection, trithionate was roughly equimolar to pentationate for first one hour of incubation and it diminished thereafter slowly with time. On the other hand, when the heated extracts were employed instead of the intact extracts, tetrathionate as substrate was little consumed all the time, and the percentage of tetrathionate recovered was $99.4 \%$. In case in which the substrate was not added to the reaction mixture, the formation of thiosulfate, sulfite, tri-, tetra-, and pentathionate was not found throughout the incubation period.

At the early stage, the equimolar formation of trithionate and pentathionate was observed, while a little thiosulfate was formed, and thereafter, the formation of thiosulfate as well as pentathionate increased with time, whereas the trithionate diminished. Huzisige and Haga $^{121}$ expressed that trithionate was biologically hydrolyzed to yield thiosulfate and sulfate with washed cells of $T$ thioparus (equation 4).

$$
\mathrm{S}_{3} \mathrm{O}_{6}^{2-}+\mathrm{H}_{2} \mathrm{O} \longrightarrow \mathrm{S}_{2} \mathrm{O}_{3}^{2-}+\mathrm{SO}_{4}^{2-}+2 \mathrm{H}^{+}
$$

If the hydrolysis of trithionate had not taken place, the formation of trithionate would proceed almost linearly with time, and would be equimolar to the pentathionate.

Accordingly, these facts suggest that tetrathionate may firstly be dismuted to yield trithionate and pentathionate, and the formed trithionate may be secondarily hydrolized to form thiosulfate and sulfate (equations 1 and 4).

Acknowledgement. The author wishes to express deep thanks to Dr. Köichi Ogata, Professor of Kyoto University, and Dr. Tatsurokuro Tochikura, Assistant Professor of Kyoto University, for their guidance and encouragement throughout this work.

12) H, Huzisige and K. Haga, Acta Phytochim., (Japan), 14, $141(1944)$. 